Article

\title{
Financial Sustainability of Local Governments in the Eyes of Finnish Local Politicians
}

\author{
Lotta-Maria Sinervo
}

Faculty of Management and Business, Tampere University, 33100 Tampere, Finland; lotta-maria.sinervo@tuni.fi

Received: 30 October 2020; Accepted: 3 December 2020; Published: 7 December 2020

\begin{abstract}
Local government aims for financial sustainability in ensuring the wellbeing of citizens at the expense of their tax incomes. As members of local councils, local politicians are the highest decision-makers who are responsible for setting the aims and evaluating the outcome of municipal operations. Hence, local politicians' notions on financial sustainability play an important role in sustainable decision-making. Although financial sustainability is seen important, previous research is limited in providing studies on the multidimensional nature of financial sustainability. Prior research has focused on the measurement of financial sustainability, often in the contexts of financial difficulties. This paper aims to answer this research gap by studying local politicians' interpretations on financial sustainability and contributing to a deeper understanding of the phenomenon. This qualitative study employs interview data collected from 24 Finnish local politicians from five municipalities. Based on the content analysis of the interview data, financial sustainability is, in the eyes of local politicians, a political issue with multiple factors in and out of the reach of decision-makers. These notions could be utilized in future research in developing methods for measuring and managing financial sustainability in local governments.
\end{abstract}

Keywords: financial sustainability; local government; local politician

\section{Introduction}

The World Commission on the Environment and Development Report (1987), better known as the Brundtland report, popularized the famous definition of sustainability as a "development that meets the needs of the present without compromising the ability of the future generations to meet their own needs" [1]. Accordingly, financial sustainability refers to the financial and economic dimensions of that ability [2]. In the context of public administration, the sustainability issue is gaining prominence on the agenda [3]. Furthermore, as a focal point of public administration, local governments have a key role in ensuring adequate and sustainable well-being for its citizens, which can be done by organizing quality public services to tax-paying inhabitants. From this basic idea of the public sector, two fundamentals of public financial management arise: (1) The public sector should have its economy and finances balanced in the long-term, which means, for instance, that taxes collected from inhabitants should be adequate to organize services for them, and (2) tax incomes should be used economically, efficiently, effectively, and equally. These fundamentals illustrate the financial sustainability of local government [4]. Failure to meet these fundamentals would result in damages to the primary purpose of the public sector and its entities [5].

However, there are many definitions regarding the concepts of financial condition or financial health in reference to financial sustainability at a local government level [6]. Within the different concepts, financial sustainability could be defined as a municipality's ability to meet its ongoing financial, capital, and service obligations in the light of resource flow and stock, drawn from annual financial information [7]. 
Furthermore, financial sustainability is often scrutinized in contexts of financial difficulties, fiscal crises, austerity policies, or cutback management [5]. In these contexts, financial sustainability is seen as a tool to track the financial condition of public administration [8]. Nevertheless, financial sustainability, as a fundamental of public financial management, should be under constant evaluation. In addition, prior research has focused on measurement and indicators of financial sustainability [9]. Additionally, while previous research does not provide a universal notion on financial sustainability, in order to understand "financial sustainability", we must know how financial sustainability is interpreted and discussed.

In this article, financial sustainability was studied in the context of sustainable decision-making in local governments. Subsequently, the financial sustainability dimensions dealt with the issue of how decision-makers formulate a knowledge base for sustainable decision-making. When investigating the financial sustainability of local governments, local politicians play a crucial role. As members of local councils, they exercise supreme decision-making powers and are ultimately responsible for committing to sustainable decision-making, setting the aims for financial sustainability, and evaluating the outcome of municipal operations and finances. Hence, the notions local politicians have on financial sustainability play an important part in sustainable decision-making. From the political viewpoint, sustainable decision-making refers the attempts for providing welfare for citizens in a (financially) sustainable way. Hence, the viewpoints of political decision-makers are scrutinized in this article in an attempt to contribute to the existing knowledge of financial sustainability.

This study aimed to investigate the interpretations of local politicians on financial sustainability when they are asked to evaluate the finances and economy of the municipalities they represent. As prior research has focused on financial difficulties, measurements, and factors affecting financial sustainability, the core of this study lies in understanding 'financial sustainability'. Prior scientific literature is limited in studying how financial sustainability is interpreted and talked about, especially from the political viewpoint. The current article tried to fill this research gap by adding knowledge on decision-makers' notions on financial sustainability to provide sophisticated understanding of decision-making aiming for financial sustainability. Additionally, most of the previous studies on financial sustainability are based on quantitative research [5], which leaves room for other types of approaches. The qualitative approach to financial sustainability as a phenomenon provides more in-depth understanding of the politicians' viewpoint. This qualitative study employed empirical data consisting of 24 semi-structured thematic interviews with local politicians collected from 5 different Finnish municipalities during the spring of 2018. The qualitative data collected underwent content analysis in order to recognize the different dimensions that Finnish local politicians refer to when they discuss their respective municipality's economy and finances. This article contributes to the discussions of financial sustainability by providing information on the perceptions and notions that local politicians hold on financial sustainability. These new insights on the subject should ultimately help future studies build and design financial sustainability management and measurement tools to meet the needs of political actors.

The article is organized as follows. First, based on the existing literature, the need for research and the focus of this study is laid out, then the concept of financial sustainability is scrutinized. This is followed by presenting the perspectives of local politicians on financial sustainability. The third part consists of data collection, the method used, and the results. Lastly, the conclusions of this study are discussed.

\section{Literature Review on Financial Sustainability}

Financial sustainability illustrates the goals of the public sector in managing its economy and finances. While financial sustainability can be discussed at a municipal level, the concept is not precisely defined as of yet. Although financial sustainability is a concept without a universal definition [6], there is a shared agreement on its importance. The international literature identifies multiple definitions of financial sustainability at the local government level [5]. The concepts of financial 
sustainability [9], fiscal sustainability [10], financial equilibrium [11], financial health [12] or fiscal health [13], financial soundness or financial viability [14], financial condition [7], financial balance [4], or resilient finances [15] are used to define the phenomenon of adequate resources for future service and financial obligations. In general terms, "sustainable" means that one is able to continue their current practices [16]. In local governments, the question is whether present activities might hinder the future capacity of local governments to provide services [17]. In addition, opposite conditions, such as financial distress and its drivers, are often used in defining financial sustainability [5].

A balanced municipal economy can be defined as an economy that has adequate resources to deliver the services required by its citizenry; this concept should be associated with the value the citizens receive for the taxes they pay [4]. Thus, financial sustainability should focus both on revenues to meet public demands and possible changes in municipal expenditure patterns. Similarly, sound financial performance as "a municipality's ability to meet its financial obligations and to satisfy its service obligations to its citizens, currently and in the foreseeable future" [14]. Three conditions must be met to secure "fiscal sustainability" in the public sector: (1) Deficits should be a temporary phenomenon balancing out the economic cycle, (2) consequently, debt should remain stable over the economic cycle, (3) except if the debt is backed by an asset of at least equal value as collateral [14]. These conditions are often referred to as the "golden rule" [18]. This golden rule refers to intergenerational equity, that is, equally dividing the burdens and benefits of public investments from one generation to the next [19]. Intergenerational equity can be closely attached with municipal finances, which can be defined as the ability a municipality has of generating enough income in a given year to cover the costs of delivering the services it needs to provide [17]. Besides the equity aspect, "financial sustainability" includes a key element of time. The economy should be balanced over a long period of time; for how long is still a topic of debate.

Therefore, despite the concepts or definitions used, any approach to financial sustainability ought to contain the required information to be able to assess whether the present activities of a local government might put their capacity to provide services in the future at risk [17]. Determining the financial position of a local government is a relatively straightforward operation. External financial statements are prepared and subjected to an independent audit to inform readers that the statements present the financial position of the organization [7]. A need to interpret, in addition to financial position, financial sustainability, may hinder this process. In addition, there is a lack of agreement on the dimension and indicators that actually represent financial sustainability [7].

In previous research, the different concepts used and define the financial condition as "a local government's ability to meet its ongoing financial, service and capital obligations based on the status of resource flow and stock as interpreted from annual financial statements" are revised [7]. Definitions can be "specific in nature or broad in scope" [7]. A specific definition of the financial condition could be solvency. Solvency could be easily measured with a financial indicator such as "fund balance as a percentage of expenditures" using data from annual financial statements [7]. This somewhat simplistic measurement has its advantages, but it would certainly simplify the phenomenon and blur the view on the real financial situation within local governments. A broader definition would refer to "a government's ability to finance its services on a continuing basis, including a government's ability to maintain existing service levels, to withstand systematic and unsystematic risk, and to meet the demands of natural change over time" [7,20], which could be measured with "40 financial and environmental indicators that reflect dimensions of financial condition and dimensions that impact financial condition, respectively, taking into account the characteristics of time, environment, multidimensional relationships, and implicit and explicit obligations" [7,21].

Brusca et al. [9] (with reference to Honadle et al. [12]) consider that Municipal financial condition represents the ability to adapt with current and future obligations and public demands through proper income tax, state transfers, and service charges while managing to sustain a certain level of public services $[9,12]$. From an internal viewpoint, the municipal financial condition can be determined in cash, budgetary, long-run, and service solvency of the entity [20]. However, it can be determined that 
that municipal revenues work within two principles: (1) Revenues from internal resources received by municipalities to finance activities that provide basic services to its inhabitants, and (2) revenues from external resources, such as governmental aids $[16,22]$. Taxes, service charges, and administrative fees (such as building permits) can be considered as internal municipal revenue sources, and governmental grants (general grants and grants for specific purposes) and loans from governmental sources and private capital markets as external municipal revenue sources [16].

As pointed out in the introduction, extensive prior research has focused on the measurement of financial sustainability. Several different models have been developed with the purpose of assessing the financial condition of a given municipality while preventing financial distress [9]. Measurement of financial sustainability can be done with a large variety of techniques, ranging from "basic approaches", such as accounting information and financial reporting analysis $[9,13,23]$, to more sophisticated statistical modeling approaches, with the aim of discriminating a financial healthy local government from a distressed one [14,24-26]. In addition, financial conditions aimed at determining the variables that can best explain financial sustainability in local government can include indicators of financial statements, such as long-term debt, cash solvency, and revenue structure [8,27]. Over the last 40 years, international literature has focused on creating models that monitor and measure the financial health and predict financial crises at a local government level [5].

Issues of financial sustainability come up to the agenda when financial difficulties appear. This interest originates from the ongoing financial crisis that involved various cities involved in the U.S. market crashes between the 1970s and the 1990s (i.e., Cleveland and New York in the 1970s; Miami, Pittsburgh, and Philadelphia in the 1990s) and, later on, from the spending reviews and austerity policies that many E.U. countries imposed on their local governments following the international crisis of $2008[5,8,17]$. The meaning of financial crisis can be seen as an opportunity to define the bases of financial sustainability good practice guidelines in order to control the use of public funds and indebtedness of government around the world [8].

There is also an increasing amount of literature on this topic that aims to identify the different factors that may provoke or accelerate harmful financial conditions [9]. Environment factors, such as socioeconomic determinants, can influence the financial condition of municipalities by assuming that they have impacts towards both the need and demand of citizens for public services as well as production costs [28-30]. Current literature has tried to analyze the impacts of the inhabitants, population density, or gross domestic product [24,31]. The effects of factors on financial sustainability can be divided into external and internal factors [5]. External factors include demographic and socioeconomic factors, such as population, population density, population wealth, unemployment, immigration, and education. Internal factors deal with managerial factors, those being, for instance, weak management culture, fiscal framework, expenditure costs, debt, and budget surpluses. Internal factors also include factors such as political fragmentation, cycle, and competition, as well as the power relations between left- and right-wing parties. Additionally, other authors consider that political and organizational factors may influence the financial condition of municipalities. The results, however, are inconclusive: Some states that conserve parties tend to have a lower level of debt [32] while others argue that there is no clear relationship between political ideologies and the level of debt [31]. Organizational factors, in turn, are perceived to affect the ability to cope with the need for changes, which will support the possibility of maintaining a financial balance [33].

All in all, prior research has focused on the measurement and prediction of financial sustainability. There are multiple studies on the different ways to measure financial sustainability. Previous studies have also focused on analyzing the factors of financial sustainability, be they external or internal. Although the literature on financial sustainability is extensive, there is a lack of studies concentrating on "financial sustainability" as a multidimensional phenomenon. Currently, financial sustainability is studied from the perspective of defining the concept and testing the application of its metrics in local government. This rather technical approach to financial sustainability excludes the examination of the multidimensional nature of the phenomenon illustrated by the multiple definitions of 
financial sustainability. Therefore, there is a clear need to study and identify financial sustainability as a phenomenon. The notions on interpreting and contemplating the phenomenon of financial sustainability are required to understand sustainable decision-making, management, and how to manage financial sustainability. Thus, the political views on financial sustainability are vital in the context of local governments.

\section{Politicians and Financial Sustainability}

As key actors of a local government's financial sustainability, local politicians decide the budget allocations that set out the frame for municipal operations. In this paper, the focus is on the political interpretations of financial sustainability. The starting point is the hypothesis that local politicians will have different kinds of interpretations of financial sustainability that might differ and conflict with the definitions drawn from the literature. Regarding these different kinds of interpretations, local politicians can be regarded as "policy actors that are the resultant of three sets of forces: their ideologies, their interests (e.g., power, reputation, financial reward) and the information they have" [34]. Next, three sets of forces are discussed in the perspective of financial sustainability. However, as Weiss (1983) highlights, this is not a universal model to explain political behavior. In reality, such a model would be more or less complex, and it might be supported by scientific research, experienced judgment, folk wisdom, or gut feeling.

Political interests can be defined primarily in terms of self-interest [34]. Politicians want to be re-elected, and they want to move to positions of greater authority. Interest represents the drama of public decision-making. In a democracy, there is a strong incentive for politicians to undermine financial sustainability as a long-term goal of public finances [35]. These incentives are implied by the logic of democratic elections, i.e., political interests. Politicians try to win elections by promising, for instance, higher subsidies, higher expenses for education or infrastructure or lower taxes, but keeping those promises would increase public spending or lower public revenues. This as a "deficit bias" that does not depend on which candidate or party wins an election: "the deficit bias is a phenomenon inherent to the system of democratic elections and politician behavior. It poses a threat to financial sustainability" [35]. In practice, this would mean that a politician's drive to be re-elected undermines the importance of financial sustainability.

Furthermore, there are primary differences between political behavior and managerial behavior. For managerial behavior, economic rationality can be a starting point, while political behavior is characterized with different rationalities. Politicians can be described as those who are constrained by "the logic of politics" with a focus on short-term thinking and obtaining re-election [36-39]. Hence, economic rationality conflicts with the logic of politics, since it does not appeal to voters. The logic of politics tends to have a negative impression or effect on the financial sustainability of local governments, as illustrated by local politicians and their attitude towards financial information [36].

Local politicians represent different interests of municipal inhabitants [40,41]. These opinions and interests can sometimes be contradictory. Therefore, it is the task of local politicians to consider every issue from different perspectives and make a decision based on the most appropriate alternative, albeit not necessarily the most sustainable [38,41].

In previous research literature, political competition tends to increase tax burden deficit and government debt while reducing available resources [42-44]. Furthermore, studies on electoral cycle theory that suggest that politicians act in opportunistic political behaviors, such as exploiting public policies to influence election results [5]. In the context of this study, political self-interest, the cyclical logic of politics, is assumed in the views of local politicians on the financial sustainability of their municipalities.

Regarding ideology, a broad range of philosophy, principles, values, and political orientation [34]. Ethical and moral values are at the core of ideology: The sanctity of human life, integrity, patriotism, among others. In the political setting, ideology incorporates values with general dispositions towards programs of action [34]. A quote from Robert E. Lane states that political ideology represents an 
evaluative-descriptive-prescriptive account of the world [34]. Simultaneously, a broad range of ethical and moral issues are encompassed on worldview; in the context of research, political orientation is studied as a factor that impacts political behavior. Additionally, in local governments, politicians are typically members of political parties. The meaning of political orientation has been another variable analyzed in previous studies $[9,42,45,46]$. A significant portion of the literature on factors affecting financial sustainability is based on the role of the political party and the political cycles [5]. Based on the findings of previous studies, left-wing parties are more likely to adopt expansionary spending policies than centrist or right-wing ones, thus leading to increased loan requirements and greater difficulties in meeting repayment obligations, which challenge financial sustainability. It is widely assumed in the literature that from a theoretical perspective, left-wing parties are more drawn to guaranteeing the distribution of wealth and the maximization of welfare policies [5]. This assumption results in an increase in public spending and the level of indebtedness of municipalities. On the other hand, right-wing parties are characterized by focusing less on welfare policies and more on budgetary discipline that induces strict control of the levels of expenditures and indebtedness of local governments $[25,47,48]$.

Politicians act based on a given basis of knowledge. Politicians have a sense of the current state of affairs, the relative seriousness of problems at hand, why things happen as they do, and which strategies of intervention will help or hinder progress, as well as how much progress is possible [34]. This category is called "information" [34]. In the context of financial sustainability, we could analyze this "information" as part of the basis of knowledge of politicians and investigate the role of actual information provided for decision-making. By doing so, we ought to acknowledge the simplification of "information".

Municipalities provide information that serves as a basis for sustainable decision-making and management. Information concerning financial sustainability typically concerns budgetary issues, such as appropriations and the expected cost of certain services, or accrual-based issues, such as the depreciation of fixed assets and equity relative to debt [49]. Financial information includes both cash-based budgetary information and accrual-based financial information. The third type of information is non-financial performance information [50]. Performance information typically refers to qualitative and quantitative information about the public sector activities, processes, services, service outcomes, and transformation processes, such as productivity/efficiency, and effectiveness [51].

The basic idea behind information production is the belief that providing local politicians with high-quality financial information would eventually result in sustainable decision-making. As identified in previous research, there is no causality in the information-decision-making nexus [52-54]. Nevertheless, decision-makers have an incentive to interpret, analyze, and use financial information [55]. In order to make good decisions, decision-makers must make sense of the financial operations and financial position of the municipalities they represent. Often, when a decision-maker talks about the financial situation of public organization, they are supposedly basing their interpretation of financial information [56]. Information use falls out the scope of this study since the aim is to identify the dimensions of financial sustainability. However, there is extensive research on political information use [57]. In addition, Finnish local politicians have been previously studied providing insights on the use of financial information [58].

\section{Data and Methods}

In Finland, there are currently two administrative levels: Central and local government, with 311 municipalities. Municipalities provide most of the public services such as health care, social services, education, cultural services, local infrastructure, housing, and planning services. Public services are mainly financed via taxes and state subsidies. Local politicians are elected members of local councils. In local councils, councilors have a clear political and governing capacity in which to shape and direct the development of their communities [59]. In Finnish local governments, local councils are responsible for the municipalities' activities and finances. They exercise the supreme 
decision-making power in municipalities. The Finnish Local Government Act (410/2015) states that the local council decides, for instance, the municipal strategy, administrative regulations, budget and financial plan, ownership policy and corporate governance principles, operating and financial objectives set for municipally owned companies, principles for managing assets and for investment activities, and principles for internal control and risk management. The council also appoints members to other municipal bodies, such as the municipal executive board and other committees.

Municipal elections are held every four years in Finland. Local councilors are part-time politicians. Municipalities have a full-time staff that oversees different functions and operations, such as preparing decisions for the local council. Municipal officials and employees operate under local council in an organizational hierarchy. As in many other European countries, council members are mainly middle-aged males. Approximately $40 \%$ of Finnish council members have an academic degree (only $9 \%$ of council members have a basic education degree). More than $80 \%$ of all the council members are employed, $12 \%$ are retired, and $4 \%$ of them are unemployed. Approximately $37 \%$ of council members are working in the municipal sector, $36 \%$ of them are private-sector employees, $7.5 \%$ are placed in the governmental sector, and $20 \%$ of them work as entrepreneurs [60]. Finnish political parties include the right-wing parties Centre party, Christian Democrats, National Coalition Party, Finns Party, and Blue Reform, and on the left, the Social Democratic Party, Left Alliance, and Green League.

This paper applied semi-structured interviews to politicians from five different municipalities in Finland. The municipalities differed in size and financial position; one was a large city (over 200,000 pop.), three were medium-sized cities (10,000 to 50,000 pop.), and one was a small municipality (under 10,000 pop.). A total of 24 interviews with local politicians were conducted from February to May 2018. The interviews lasted from 52 to $101 \mathrm{~min}$ and were recorded and transcribed in full (99,093 words) with the consent of the interviewees. The implementation of the analysis was considerably easier after the audio recordings were converted to text. Respondents were mainly men $(54.2 \%), 47$ years old on average and highly educated ( $75 \%$ had a university degree). Twenty-one percent were pensioners. Most come from communication and brokerage professions. Fifty-eight percent of local politicians were from right-wing parties, and $42 \%$ from left-wing parties. Thirty-eight percent of the respondents were first-time politicians. Experienced politicians (63\%) were those with more than one term in local council, and on average, they have two full terms on the council.

A set of semi-structured thematic interviews were conducted for this research. Interviewees were asked to describe the general financial operations and financial position of the municipalities they represent. They were given the opportunity to form opinions and beliefs freely and over time. Supportive questions, such as "what helps you form your understanding on the financial conditions or position of your municipality" or "what do you consider to be important in municipal finances in general" were asked when needed.

As mentioned above, the data used in the analysis comes from interviews with local politicians. In this paper, I propose that textual analysis represents a valuable methodological approach for analyzing the notions of local politicians on financial sustainability. Thus, the methodological approach here is qualitative. Textual analysis has been popular, especially for researchers working in different areas of social sciences [61]. This procedure may include different methodologies, such as narrative, discourse, and content analysis [62]. Within the textual analysis, a researcher can focus either on a few selected factors of the textual data, or many factors at the same time. This ensures an "open process", which in turn can improve dialogue across different research areas and theories [62].

The purpose of this study was to assess the dimension of financial sustainability in local politicians' speech. The usefulness of textual analysis lies within the analysis of the different dimensions used to refer to the financial sustainability of municipalities. In content analysis, the data is analyzed in detail, and extra attention is paid to similarities and differences. However, as with all approaches, the textual analysis also has some limitations that should be considered. The main limitation of all types of textual analysis is the need to illustrate the reliability of the ways used to collect data and consequent validity and replicability of observations drawn from them [63]. Reliability is referred to as the 
consistency of the analysis and the reproducibility of the results. Validity, on the other hand, involves the compatibility of the used methods and set research questions. In this paper, I ensured the validity by a thorough examination of the literature. A detailed description of the research process, material, and conclusions are drawn to enable the research to be monitored and thus promote repeatability of future qualitative studies.

Perspectives from the existing literature are the starting point of the content analysis of the data. Therefore, an analytical frame was formulated to identify the dimensions of financial sustainability, as well as the factors and hindrances of financial sustainability in local government. Here, I applied the perspectives of ideology and interest complemented with the viewpoints of previous research on factors affecting financial sustainability. As a part of interests, self-interest and aims for re-election were scrutinized in connection to financial sustainability. Ideology is analyzed by asking how political orientation is expressed when describing the financial sustainability of their municipality.

Previous literature identifies a set of factors affecting financial sustainability in local government. In this article, I used Garmini and Grossi's categories to analyze how these factors are reflected in the speech of local politicians [5]. Table 1 summarizes of the external and internal factors of financial sustainability.

Table 1. External and internal factors of financial sustainability (adapted from Garmini and Grossi 2018 [5]).

\begin{tabular}{|c|c|}
\hline External Factors & Internal Factors \\
\hline Demographic & Political \\
\hline Population & Political ideology \\
\hline $\begin{array}{l}\text { Suburbanization trends and mobility of people } \\
\text { and business }\end{array}$ & Political interests \\
\hline $\begin{array}{c}\text { Geographical position and location of the } \\
\text { municipality }\end{array}$ & Managerial \\
\hline Cyclical economic change & Mismanagement and culture \\
\hline Local economic conditions, fields of economy & Fiscal governance and rules \\
\hline Socioeconomic & $\begin{array}{c}\text { Typology of expenditure, revenues, and other } \\
\text { budget items }\end{array}$ \\
\hline Local wealth & Governance model \\
\hline Unemployment & Decentralization strategies \\
\hline Dependent population & Amalgamation and merger strategies \\
\hline Level of Education & \\
\hline Aging housing stock and aging of other infrastructure & \\
\hline
\end{tabular}

Financial sustainability originates from the term "sustainable development", dating back to the 1987 Brundtland Commission's report on the global environment and development [64]. The term has a rather long history of sustainability and sustainable development based on the "golden rule" in the context of intergenerational justice. Similarly, this idea is embedded in the definition of financial sustainability when it refers the ability to meet the needs of the present citizenry without compromising the ability to meet future needs [2]. This question of the temporal dimension of financial sustainability is investigated in the data analysis.

\section{Results}

This section outlines the results of the content analysis carried out through interviews with Finnish local politicians. Results are scrutinized from the perspectives of external and internal factors of financial sustainability. Especial focus is given to the 'politics' of financial sustainability. First, local politicians described municipal finances and financial position in various ways. Definitions of financial sustainability of the municipality varied greatly from short and quick answers with adjectives or school grades to lengthy reflections on the different dimensions of financial sustainability. 
"in one word: appalling [ $\ldots]$ ]"

"for me, a financially sustainable economy is a means to organize services. We need to have a balanced economy to organize services otherwise it would just be about 'putting out fires' inevitably with a shortsighted view on operations $[\ldots]^{\prime \prime}$

In their descriptions, respondents often connected financial sustainability to the raison d'etre of local government, the reasons why municipalities exist, and the role and obligations they have. The local politicians highlighted that municipalities are for citizens and their well-being. However, clearly financial sustainability or municipal economy was not high in their agendas. Some of the respondents ruled out the meaning of the municipal economy and concentrate on the good quality services without pondering the question of costs. Given that financial sustainability is typically interpreted through the incomes and expenditures of a municipality, respondents frequently answered questions on finances mentioning the main sources of income and main types of expenditures and services required from their municipalities. However, some of the respondents highlighted the meaning of financial sustainability as:

"Financial sustainability is not an end in itself; it is a means to organize services for citizens.

We need to make citizens feel that this is a nice and safe place to live, and the city organizes the services reasonably."

Based on the data, respondents had some principles and rules they followed in their council and in their perception of financial sustainability. For instance,

"We need to balance our expenditure based on the income, always. The city should never take loans for operative actions only for investments."

\subsection{Shifts in Economic Cycles as External Factors of Financial Sustainability}

During the interviews, respondents were asked about the hindrances of reaching a financially sustainable municipality. The most common issues identified in the data were the meaning of shifts in economic cycles. Respondents talked about these shifts, and the impact on the financial sustainability of their municipality, and the impact on tax income was clearly recognized by the respondents. Furthermore, the frustration regarding the limited possibilities to influence these shifts was shared among respondents. Municipalities were seen to be in the mercy of the economic cycle whose only aim is to survive.

"I would say that financial sustainability is the ability to react for changing situations, to create a kind of bumper for surprises to come so that we can find ways and flexibility to survive. Putting it simply, we need to control our expenses and have a strategy for gaining future incomes in order to survive."

Due to the economic cycle shifts, unemployment, lower numbers of jobs, local effects such as a closing of a local factory, and the mobility of people to bigger cities were all factors that respondents referred to when talking about the financial conditions of their municipality. Local politicians believed that these factors were out of their reach or that they had limited possibilities to tackle these issues. As one local politician said:

"Our tax incomes are decreasing, unemployment rates are above average, and our population is diminishing, these are the worst. In addition, our operating expenditures are increasing, and they are always exceeding budget appropriations, we have no control over them."

Apart from that, changes made in government legislation were regarded as out-of-reach of political decision-making. New obligations for municipalities and cuts in state grants were examples of the ambiguous relationship between local and central levels of government affecting the financial sustainability of local government. 
"During the last five years, state grants have decreased seven million which is a huge amount of money and a high percentage of our budget of 100 million [ ... ]"

In addition, the impact of governance and organization of certain municipal services can be detected from the data. Respondents felt that healthcare services, typically organized by hospital districts and not by the municipalities themselves, were clearly seen as hindrances of financial sustainability. Municipalities have little control over the expenditures of hospital districts. Thus, local politicians felt that municipalities have the role of merely "picking up the tab".

As for broader issues, such as cutback management and cost reduction, typical aspects to financial sustainability, respondents regularly talked about financial sustainability in the context of financial difficulties and particularly of reductions and savings, as illustrated by the following quote:

“The aim of the municipality is not to profit, but it's not to make cuts either. Sometimes I feel conversations are this type that the main aim of our municipality is to save money $[\ldots]$ ]"

\subsection{Organizational Culture as an Internal Factor of Financial Sustainability}

When respondents were asked to ponder the hindrances of financial conditions, management issues, decision-making, and organizational culture come up. Some of the respondents remarked on obstacles for financial sustainability in the administration that they were not content with, such as the quality of administrative preparation work. Others expressed that issues on the meeting agenda were promptly prepared and information thoroughly provided. In addition, respondents illustrated the issues of organizational and decision-making culture as the harmful way of doing things and challenges to financial sustainability:

"Our utilities are rotten, and the council is not really even interested in how to keep them in good condition. Year after year, the same mistakes are made."

Furthermore, respondents saw the issues of competence and financial expertise of local politicians as a clear hindrance to financial sustainability. As two respondents put it:

"One time a few years ago, we were laughing with our council chair that that was an 8.5 million decision and almost no one took the stand $[\ldots]$ "

“There were opinions that our municipality has a 'bottomless purse' and that it just needs to offer all the good and nice things that citizens want. Local politicians want to promise everything and those are the same people who won't take part in council workshops to learn about municipal finances. God forbid they might learn something that they couldn't deny on a citizen's forum $[\ldots]$ ]"

These types of concerns were shared in the data. Respondents were worried about the financial competence of their local council, as illustrated in multiple comments on the shortsightedness, slowness, and vagueness of decision-making.

"Long-term thinking and planning seem very difficult, and the focus is easily converted to more understandable issues when concentrated on matters of small sums of money."

\subsection{A Key Element of Financial Sustainability: Use of Resources}

Apart from the difficulties with management and decision-making, one clear topic in their interpretations of financial sustainability is the use of the municipalities' resources. Questions on how the resources are used to complement the questions of how much and what kind of resources the municipality has. Interviewees had the sense that municipal operations must be organized economically, efficiently, and effectively, with "common sense". Respondents highlighted the issue of performance and outcomes in the connection of financial sustainability. However, the aspect of performance as a dimension of financial sustainability is not a simple one; rather, it is complex by nature and needs further contemplation, as illustrated by one interviewee: 
"In case of lots of incomes, even poorly performed operations turn out profitable $[\ldots]$ "

Overall, based on the analysis of the data, respondents saw financial sustainability two-fold: As income and expenditure. Expenditure is, or should be, in the control of a municipality, and as such, in reach of political decision-making. In their interviews, local politicians expressed the need for more opportunities to impact the expenditures of the municipality. Expenditure was also closely related to questions of performance. On the other hand, income is seen only limitedly in the reach of political decision-making. Politicians perceive income as vital but "external", in the sense that a revenue base cannot be increased by a given municipality's actions, at least not in the short term. Long-term policymaking in municipalities can boost the local economy, and land use planning can attract new inhabitants to strengthen the revenue base. Naturally, the matter of tax rates "as the only possibility" is vital in the context of securing adequate incomes.

\subsection{Politics of Financial Sustainability}

As a part of the analytical framework utilized in the analysis, political ideology and interests were scrutinized in the data. When analyzing the impact of political ideology, the data showed that respondents frequently ponder the aspects of left-wing-right-wing politics when reflecting on financial sustainability. For instance, right-wing politicians more typically highlighted tax rates as the key question of financial sustainability with the idea that income and expenditure should not be balanced only by raising tax rates.

"Last year we did not raise tax rates, but in 2016, when I was a deputy council member, the arguments were year after year that we should have higher tax rates. I am against it; I see that we cannot pour increasing costs on the citizens' necks. Higher taxes are not always the solution. At the same time, left-wing politicians see that that's the way to even out the income gaps between citizens. That is not true."

Right-wing politicians believed that keeping tax rates stable would automatically create a spirit for positive development and innovations. Financial sustainability should be reached by balancing the expenditure to meet the framework of current tax incomes. However, left-wing politicians typically saw tax rates as a more flexible income, as a left-wing politician states:

"When the third factory closed in our municipality, I thought that this was such a crisis that now tax rates could actually 'live' $[\ldots$ ]"

Another political issue raised was the matter of organization. For instance, daycare services could have their own resources provided by the municipality or outsourced to a private company. This matter was related to financial sustainability in discussions on how resources were allocated and used, i.e., performance discussions.

"And these different political interests collide, and you hear from the left 'no, no, no, we want to do it the same way like before, no matter the costs, just raise tax rates [ ... ]"

"It is this right-wing ideology that the public sector should be slim, and this ideology is regarded as some kind of self-evident fact. But that is thoroughly crooked. They don't actually think that the public sector should be slim, they just want to make a profit out of our taxes while outsourcing public services to private companies $[\ldots]^{\prime \prime}$

Besides the left-wing-right-wing aspects of sustainable decision-making, the impact of different parties was regarded by the interviewees as characteristic to political decision-making to reconcile the different approaches. These were regarded as hindrances to financial sustainability, as seen in a quote from a right-wing local politician:

"Greens just want enormously different things because they know that at the end Coalition party will pay the bill $[\ldots]$ ]" 
Regarding political interests, another interesting issue was the "politicking" that emerged in the data. Several respondents pointed out that "pulling homewards" hinders financial sustainability. Sometimes political interests overcome the interest of the city as a whole.

"The worst thing is that everyone wants to save their neighborhood school."

This could also be a matter of decision-making culture taking place in local councils. Respondents shared their experiences on redundancies of resources and cost cuts with the notions that these decisions are difficult to make and they are often heavily criticized later. Understandably, cutting down on services and lowering the level of service quality are hard decisions, and politicians receive negative feedback from citizens. This makes sustainable decision-making even more difficult, as illustrated by the words of one respondent:

"As a local politician, you only want to hear positive feedback. In the council hall, we all agree that we have to make these difficult decisions. When you walk out the door and meet the first citizen saying that you are making wrong decisions, it is tempting to change your mind. It is so hard to stand by the difficult decisions $[\ldots]$ ]"

It is not surprising that after austere measures, when things are looking brighter, a room for politicking opens. This politicking was widely regarded as an obstacle to obtain financial sustainability.

"It is important to have the ability to raise taxes when needed, but it is not a blissful end.

When there is more money, there are even more takers and money pits [ ... ]"

"After these hard austerity decisions, next year our financial statements looked rather good so immediately discussions on was this necessary burst $[\ldots]$ "

Furthermore, the issue of a political cycle is an evident hindrance on sustainable decision-making. Respondents admitted that a four-year political cycle is a short time to promote financial sustainability. Upcoming elections are in sight of politicians, and 'campaigning' is mentioned in the interpretations of financial sustainability:

"Well, I am going to take the floor and suggest that now that we have so much surplus, we can afford to decrease tax rates ... As I said elections are coming [laughing]"

All in all, political interests and ideology seem to greatly affect financial sustainability in the eyes of local politicians, increasing risks for complex and short-term decision-making.

\section{Conclusions and Discussion}

The aim of this article was to identify different notions of financial sustainability based on the description by local politicians of the financial position and the conditions of the municipality they represent. Political perspectives on financial sustainability have been previously studied as part of the factors that provoke or accelerate a given financial condition. Here, the focus is on the political notions of financial sustainability.

Based on the results of the study, politicians often reflect on financial sustainability when they talk about their municipality. However, one of the crucial points is that the multiple ways to understand financial sustainability can range from grading financial sustainability to exhaustive ponderations of different factors regarding the matter. The factors identified by local politicians were similar to the types studied in the literature.

While there is no universal notion of financial sustainability in local government, based on a literature review, certain dimensions on financial sustainability can be identified. Financial sustainability can be defined as "three intertwined dimensions of long-term financial sustainability: service dimension, revenue dimension and debt dimension" [9]. These dimensions reflect the different perspectives on financial sustainability in local government: Revenues should be adequate for service responsibilities 
without running into long-term debt. Therefore, financial sustainability dimensions include perspectives on satisfactory quality of services and adequacy of revenues in the long run. This expands the definition of financial sustainability from the narrow perspectives of (financial) metrics. The concept of financial sustainability can also be seen as extremely exhaustive [5]. In the context of this study, the view of local politicians on financial sustainability typically included the three intertwined dimensions [9]. Politicians tended to highlight the dimension of services in their views on financial sustainability. The service dimension is closely linked to the basic fundamentals, the reasons and the roles of municipal government.

In the literature, the question of performance of municipalities is not often connected with financial sustainability. However, based on the results of this study, local politicians see this as a vital part of financial sustainability, and they highlight the issue of performance and outcome as not simply a question of the adequacy of resources, but as wider questions of the use and outcomes municipal resources. Often financial sustainability is scrutinized from a rather narrow perspective, focusing on financial resources instead of looking at what was achieved with the use of those resources. As a potential direction of future research, sustainability could be studied more widely, combining financial and economic perspectives to social directions of sustainability [65].

In their interpretations of financial sustainability, politicians contemplated the different aspects recognized in previous studies. However, the political interpretation of financial sustainability provided new insights on the topic. Financial sustainability was associated with factors that are in and out of the reach of politicians. Demographic and socioeconomic features were those that politicians felt that they had limited possibilities to affect. One of the most important factors that came up regularly in the data was the impact of economic cycles on the financial sustainability of local government. Based on the analysis of the data, besides location and the local field of economy, global shifts in economic cycles are a key aspect of financial sustainability. Thus, prior research has focused on financial difficulties as a context to study financial sustainability [8]. However, more studies on the meaning of global shifts of economic cycles in the sustainable management of municipalities are needed.

Based on the data collected from Finnish local politicians, financial sustainability seems to be a highly political issue. Similar to previous studies that identify politics as a factor that impacts financial sustainability [42], the results of this study confirm the significant impact that political behaviors and challenges have on sustainable decision-making and management. Politicians themselves recognized the logical aspects of politics to create challenges and promote financial sustainability. Based on this study, "politics" is about the impact of political orientation, political cycles, and competition, similar to what is concluded in previous research [5]. This political dimension of sustainability [2] is an interesting research agenda for future studies.

This article is a case study of Finnish local politicians. Naturally, a case study and the qualitative empirical data from interviews have its limitations. Qualitative empirical data is always limited in showing the quantities or frequencies of particular topics. This as a limitation should be recognized when the results of the study are pondered.

Overall, financial sustainability is, in the eyes of local politicians, a challenge they try to tackle in the decision-making when contemplating the responsibilities and resources of the municipality they represent. This challenge includes elements in and out of reach of political decision-making, which makes the request for financial sustainability even more challenging.

Funding: This research received no extra funding.

Conflicts of Interest: The author declares no conflict of interest. 


\section{References}

1. World Commission on Environment and Development (WCED). Our Common Future; Oxford University Press: Oxford, UK, 1987.

2. Borgonovi, E.; Adinolfi, P.; Palumbo, R.; Piscopo, G. Framing the Shades of Sustainability in Health Care: Pitfalls and Perspectives from Western EU Countries. Sustainability 2018, 10, 4439. [CrossRef]

3. Fiorino, D. Sustainability as a Conceptual Focus for Public Administration. Public Adm. Rev. 2010, 70, s78-s88. [CrossRef]

4. Sinervo, L.-M. Interpreting financial balance in local government: A case study from Finland. Public Money Manag. 2014, 34, 123-130. [CrossRef]

5. Garmini, S.; Grossi, G. Financial Sustainability and Intergenerational Equity in Local Governments; Bolívar, M.P.R., Subires, M.D.L., Eds.; IGI Global: Hershey, PA, USA, 2018; pp. 179-205.

6. Dollery, B.; Crase, L. A Comparative Perspective on Financial Sustainability in Australian Local Government; Centre for Local Government, School of Economics, University of New England: Armidale, NSW, Australia, 2006.

7. Riverbark, W.C.; Roenigk, D.j.; Allison, G.S. Conceptualixing financial condition in local government. J. Public Budg. Account. Financ. Manag. 2010, 22, 149-177.

8. Pina, V.; Bachiller, P.; Ripoll, L. Testing the Reliability of Financial Sustainability. The Case of Spanish Local Governments. Sustainability 2020, 12, 6880. [CrossRef]

9. Brusca, I.; Rossi, F.M.; Aversano, N. Drivers for the Financial Condition of Local Government: A Comparative Study Between Italy and Spain. Lex Localis J. Local Self-Gov. 2015, 13, 161-184. [CrossRef]

10. Bergmann, A. Public Sector Financial Management; Pearson Education Limited: London, UK, 2009.

11. Jones, S.; Walker, G. Explanators of local government distress. Abacus 2007, 63, 396-418. [CrossRef]

12. Honadle, B.W.; Costa, J.M.; Cigler, B.A. Fiscal Heath for Local Governments; Elsevier Academic Press: San Diego, CA, USA, 2004.

13. Kleine, R.; Kloha, P.; Weissert, C.S. Monitoring Local Government Fiscal Health. Gov. Financ. Rev. 2003, 19, 18-23. [CrossRef]

14. Cohen, S.; Doumpos, M.; Neofytuo, E.; Zopounidis, C. Assessing financial distress where bankruptcy is not an option: An alternative approach for local municipalities. Eur. J. Oper. Res. 2012, 218, 270-279. [CrossRef]

15. Fuchs, S.; Bergmann, A.; Brusca, I. Using Financial Reporting for Decision Making as a Measure Towards Resilient Government Finances: The Case of Switzerland. Lex Localis J. Local Self-Gov. 2017, 15, 133-153. [CrossRef]

16. Hajilou, M.; Mirehei, M.; Amirian, S.; Pilehvar, M. Financial Sustainability of Municipalities and Local Governments in Small-Sized Cities; a Case of Shabestar Municipality. Lex Localis J. Local Self-Gov. 2018, 16, 77-106. [CrossRef]

17. Bolívar, M.P.R.; Galera, A.N.; Muñoz, L.A.; Subirés, M.D.L. Factors Influencing Local Government Financial Sustainability: An Empirical Study. Lex Localis J. Local Self-Gov. 2014, 12, 31-54. [CrossRef]

18. Burrit, R.L.; Schaltegger, S. Sustainability accounting and reporting: Fad or trend? Account. Audit. Account. J. 2010, 23, 829-846. [CrossRef]

19. Groneck, M. The golden rule of public finance and the composition of government expenditures: A growth and welfare analysis. J. Econ. Policy Reform 2011, 14, 273-294. [CrossRef]

20. Groves, S.M.; Valente, M.G. Evaluating Financial Condition: A Handbook for Local Government, 4th ed.; International City/County Manager Association (ICMA): Washington, DC, USA, 2003.

21. Berne, R. Measuring and Reporting Financial Condition. In Handbook of Public Administration, 2nd ed.; Perry, J.L., Ed.; Jossey-Bass Publishers: San Francisco, CA, USA, 1996.

22. Montazeri, R.; Khodaei, Z. The role of sustainable revenue sources in revenue sources of municipalities. Urban Econ. 2012, 13, 25-39.

23. Rossi, F.M. Analysis of solvency in Italian local Governments: The impact of Basel II. IUP J. Financ. Risk Manag. 2011, 8, 17-42.

24. Zafra-Gomez, J.L.; Lopez-Hernandez, A.M.; Hernandez-Bastida, A. Developing an alert system for local governments in financial crisis. Public Money Manag. 2009, 29, 175-181. [CrossRef]

25. Garcia-Sanchez, I.M.; Mordan, N.; Prado-Lorenzo, J.M. Effect of the political system on local financial condition: Empirical evidence for Spain's largest municipalities. Public Budg. Financ. 2012, 32, 40-68. [CrossRef] 
26. Rossi, F.M.; Zito, M.; Costanzo, A. How to prevent distress in local government: A new model applied in Italy. Proc. ARSA Adv. Res. Sci. Areas 2012, 1, 627-631.

27. López Subires, M.D.; Muñoz, L.A.; Galera, A.N.; Bolívar, M.P.R. The Influence of Socio-Demographic Factors on Financial Sustainability of Public Services: A Comparative Analysis in Regional Governments and Local Governments. Sustainability 2019, 11, 6008. [CrossRef]

28. Capalbo, E.; Grossi, G. Assessing the influence of socioeconomic drivers on Italian municipal financial destabilization. Public Money Manag. 2014, 34, 107-114. [CrossRef]

29. Andrews, R.; Boyne, G.A.; Law, J.; Walker, R.M. External constraints on local services standards: The case of comprehensive performance assessment in English local government. Public Adm. 2005, 83, 639-656. [CrossRef]

30. Boyne, G.A.; Ashworth, R.E.; Powell, D.M. Environmental change, leadership succession and incrementalism in local government. J. Manag. Stud. 2001, 38, 859-878. [CrossRef]

31. Vicente, C.; Ríos, A.M.; Guillamón, M.D. Voting behavior and budget stability. Rev. Contab. Span. Account. Rev. 2013, 16, 46-52. [CrossRef]

32. Kiewiet, R.; Szalaky, K. Constitutional limitations on borrowing: An analysis of state bonded indebtedness. J. Law Econ. Organ. 1996, 12, 62-97. [CrossRef]

33. Carmeli, A.; Cohen, A. The financial crisis of the local authorities in Israel: A resource-based analysis. Public Admin. 2001, 79, 893-913. [CrossRef]

34. Weiss, C.H. Ideology, Interests and Information: The Basis of Policy Positions. In Ethics, The Social Sciences and Policy Analysis; Callahan, D., Jennings, B., Eds.; Plenum Press: New York, NY, USA; London, UK, 1983; pp. 213-245.

35. Slembeck, T.; Jans, A.; Leu, T. A politico-economic perspective on financial sustainability. J. Public Budg. Account. Financ. Manag. 2014, 26, 140-164. [CrossRef]

36. Buylen, B.; Christiaens, J. Talking Numbers? Analyzing the Presence of Financial Information in Councilors Speech During the Budget Debate in Flemish Municipal Councils. Int. Public Manag. J. 2016, 19, 453-475. [CrossRef]

37. Van Dooren, W. What makes organisations measure? Hypotheses on the causes and conditions for performance measurement. Financ. Account. Manag. 2005, 21, 363-383. [CrossRef]

38. Tiili, M. Strategic political steering exploring the qualitative change in the role of ministers after NPM reforms. Int. Rev. Adm. Sci. 2007, 73, 81-94. [CrossRef]

39. Liguori, M.; Sicilia, M.; Steccolini, I. Politicians versus managers: Roles and interactions in accounting cycles. Int. J. Public Sect. Manag. 2009, 22, 310-323. [CrossRef]

40. Buylen, B.; Christiaens, J. Why are Some Flemish Municipal Party Group Leaders More Familiar with NPM Principles than Others? Assessing the Influence of Individual Factors. Lex Localis J. Local Self-Gov. 2014, 12, 79-103. [CrossRef]

41. Hansen, K. Local councillors: Between local 'government' and local 'governance'. Public Adm. 2001, 79, $105-123$. [CrossRef]

42. Navarro-Galera, A.; Lara-Rubio, J.; Buenida-Carrillo, D.; Rayo-Canton, S. What can increase the default risk in local governments? Int. Rev. Adm. Sci. 2017, 83, 397-419. [CrossRef]

43. Benito, B.; Bastida, F.; Vicente, C. Political Budget Cycles in Local Governments. Lex Localis J. Local Self-Gov. 2012, 10, 341-361. [CrossRef]

44. Ashworth, J.; Geys, B.; Heyndels, B. Government Weakness and Local Public Debt Development in Flemish Municipalities. Int. Tax Public Financ. 2005, 12, 395-422. [CrossRef]

45. Cabaleiro, R.; Buch, E. Impact of size and geographic location on the financial condition of Spanish municipalities. Transylv. Rev. Adm. Sci. 2011, 34, 22-39.

46. Bastida, F.; Benito, B.; Guillamón, M.D. An Empirical Assessment of the Municipal Financial Situation in Spain. Int. Public Manag. J. 2009, 12, 484-499. [CrossRef]

47. Garcia-Sanchez, I.M.; Mordan, N.; Cuadrado-Ballesteros, B. Do electoral cycles affect local financial health? Policy Stud. 2014, 35, 533-556. [CrossRef]

48. Allers, M.; De Haan, J.; Sterks, C. Partisan Influence on the Local Tax Burden in the Netherlands. Public Choice 2001, 106, 351-363. [CrossRef]

49. Van Helden, J. Literature review and challenging research agenda on politicians' use of accounting information. Public Money Manag. 2016, 36, 531-538. [CrossRef] 
50. Liguori, M.; Sicilia, M.; Steccolini, I. Some like it non-financial ... Politicians' and managers' views on the importance of performance information. Public Manag. Rev. 2012, 14, 903-922. [CrossRef]

51. Van Helden, G.; Hodges, R. Public Sector Accounting and Budgeting for Non-Specialists; Palgrave: London, UK, 2015.

52. Moynihan, D.P. What Do We Talk about When We Talk about Performance? Dialogue Theory and Performance Budgeting. J. Public Adm. Res. Theory 2006, 16, 151-168. [CrossRef]

53. Melkers, J.; Willoughby, K. Models of Performance-Measurement Use in Local Governments: Understanding Budgeting, Communication, and Lasting Effects. Public Adm. Rev. 2005, 65, 180-190. [CrossRef]

54. Siverbo, S.; Johansson, T. Relative performance evaluation in Swedish local government. Financ. Account. Manag. 2006, 22, 271-290. [CrossRef]

55. Van Helden, G.J.; Johnsen, Å.; Vakkuri, J. The life-cycle approach to performance management: Implications for public management and evaluation. Evaluation 2012, 8, 159-175. [CrossRef]

56. Van Dooren, W.; Van de Walle, S. Performance Information in the Public Sector: How It Is Used; Palgrave Macmillan: London, UK, 2008.

57. Demaj, L.; Summermatter, L. What Should We Know About Politicians' Performance Information Need and Use? Int. Public Manag. Rev. 2012, 13, 85-111.

58. Sinervo, L.-M.; Haapala, P. Presence of financial information in local politicians' speech. J. Public Budg. Account. Financ. Manag. 2019, 31, 558-577. [CrossRef]

59. Copus, C.; Sweeting, D.; Wingfield, M. Repoliticising and redemocratising local democracy and the public realm: Why we need councillors and councils. Policy Politics 2013, 41, 389-408. [CrossRef]

60. Statistics Finland. Kunnallisvaalit 2017. Available online: https://www.stat.fi/til/kvaa/2017/04/kvaa_2017_04_ 2017-04-27_fi.pdf (accessed on 23 November 2020).

61. Loughran, T.; McDonald, B. When Is a Liability Not a Liability? Textual Analysis, Dictionaries, and 10-Ks. J. Financ. 2011, 66, 35-65. [CrossRef]

62. Fairclough, N. Analysing Discourse: Textual Analysis for Social Research; Routledge: London, UK, 2003.

63. Milne, M.J.; Adler, R.W. Exploring the reliability of social and environmental disclosures content analysis. Account. Audit. Account. J. 1999, 12, 237-256. [CrossRef]

64. Redclift, M. Sustainable development (1987-2005): An oxymoron comes of age. Sust. Dev. 2005, 13, $212-227$. [CrossRef]

65. Oh, Y.; Jeong, S.-H.; Shin, H. A Strategy for a Sustainable Local Government: Are Participatory Governments More Efficient, Effective, and Equitable in the Budget Process? Sustainability 2019, 11, 5312. [CrossRef]

Publisher's Note: MDPI stays neutral with regard to jurisdictional claims in published maps and institutional affiliations.

(C) 2020 by the author. Licensee MDPI, Basel, Switzerland. This article is an open access article distributed under the terms and conditions of the Creative Commons Attribution (CC BY) license (http://creativecommons.org/licenses/by/4.0/). 